\title{
Efektivitas Program Pelatihan untuk Meningkatkan Perilaku Asertif dan Perilaku Pembela pada Situasi Perundungan Sekolah Dasar Kelas V
}

\section{Effectiveness of Training Program to Enhance Assertive and Defender Behavior in Bullying Situation of $5^{\text {th }}$ Grade}

\author{
Veronica Novelina Parapat ${ }^{1}$, Lucia RM Royanto ${ }^{2}$ \\ ${ }^{I}$ Fakultas Psikologi, Universitas Indonesia, Depok, Jawa Barat, Indonesia \\ ${ }^{2}$ Fakultas Psikologi, Universitas Indonesia, Depok, Jawa Barat, Indonesia
}

\begin{abstract}
KATA KUNCI Perundungan, program pelatihan, asertif, pembela, sekolah dasar

KEYWORDS Bullying, training program, assertive, defender, elementary school
\end{abstract}

Prevalensi terjadinya perundungan di Indonesia pada tingkat sekolah dasar semakin tinggi. Salah satu penyebabnya adalah individu mulai berusaha mencari status dalam lingkungan sosial. Kasus perundungan juga menjadi perhatian bagi sekolah dasar $X$ dan $Y$ di Jakarta. Adanya penguatan dari saksi terhadap aktivitas perundungan atau sikap keengganan melindungi korban menjadi salah satu faktor yang berpengaruh besar pada terjadinya perundungan. Oleh karena itu, program pelatihan bagi siswa sekolah dasar diberikan untuk meningkatkan perilaku asertif dan pembela saat menghadapi situasi perundungan. Program ini dapat membantu pihak sekolah mengurangi perundungan yang terjadi di sekolah. Penelitian ini menggunakan metode kuasi eksperimental dengan desain penelitian pre-test/post-test between subjects. Jumlah partisipan penelitian adalah 46 siswa kelas $V$, dengan diantaranya 23 siswa pada kelompok yang diberikan pelatihan dan 23 siswa pada kelompok yang tidak diberikan pelatihan. Teknik analisis data Independent Sample T-test digunakan untuk melihat perbandingan skor rata-rata antara dua kelompok. Hasil penelitian menunjukkan tidak terdapat perbedaan perilaku asertif dan perilaku pembela yang signifikan antara kelompok yang diberikan pelatihan dan kelompok yang tidak diberikan pelatihan. Meski demikian, berdasarkan hasil analisis kualitatif terdapat peningkatan penggunaan strategi membela korban pada kelompok yang diberikan pelatihan. Penelitian selanjutnya perlu mempertimbangkan durasi program pelatihan yang lebih panjang dan jenis kegiatan bermain peran untuk mendapatkan perubahan perilaku yang signifikan. Selain itu, penggunaan metode self-report perlu untuk dipertimbangkan kembali pada siswa sekolah dasar mengingat hal ini dapat menyebabkan bias. 
The prevalence of bullying in Indonesia at elementary school level is increasing. One of the causes is the individual trying to find status in the social environment. Bullying is also a concern in $X$ and $Y$ elementary schools in Jakarta. The reinforcement by bystander to bullying activity or their reluctance to protect the victims are main factors that encourage the occurrence of bullying. Therefore, training program for elementary school students are given to enhance assertive and defender behavior in bullying situation. This program can help the school decrease bullying occurance in school. This research used quasiexperimental method with pre-test / post-test between subject design. The number of participants in this research was 46 students in $5^{\text {th }}$ grade, of which 23 students in the group were given the training and 23 others were not given the training. The data analysis technique Independent Sample T-test was used to see the comparison of the average scores between these separate two groups. The results showed that there were no significant differences in assertive and defender behavior between these two groups. However, based on the results of qualitative analysis there was an increase in the use of strategies to defend the victim in the group of students who were given the training. Further research needs to consider the longer duration of training programs and types of role-playing activities to get significant behavioral changes. Furthermore, self-report method needs to be reconsidered in elementary school students considering this can cause biased.

\section{PENDAHULUAN}

\section{Latar Belakang}

Kasus perundungan merupakan salah satu masalah yang sering terjadi dalam interaksi kelompok sosial. Menurut Espelage dan Swearer (dalam Polanin, Espelage, \& Pigott, 2012), perundungan sudah meluas terjadi di sekolah. United Nation International Children's Fund (UNICEF) pada tahun 2016 menempatkan Indonesia pada posisi pertama dengan jumlah $84 \%$ kasus kekerasan anak di sekolah (Sindonews.com, 2017). Berdasarkan hasil penelitian Midgett, Doumas, Sears, Lundquist, dan Hausheer (2015), jumlah kasus perundungan semakin tinggi pada jenjang SD dan SMP. Lebih lanjut, prevalensi terjadinya perundungan semakin tinggi pada jenjang SD (Midgett, dkk., 2015). Menurut Gifford-Smith dan Brownell (dalam Craig, 2016), perundungan yang terjadi di tingkat sekolah dasar meningkat karena individu sedang dalam tahap perkembangan yang lebih banyak menghabiskan waktu bersama dengan teman sebaya. Jumlah kelompok pertemanan semakin meningkat dan identitas sosial sudah terbentuk, sehingga anak berusaha mencari status dalam lingkungan sosial (Juvenon \& Galvan dalam Craig, 2016).

$$
\text { Menurut Rodkin (2012), }
$$
perundungan terjadi saat adanya ketidaksetaraan, perlakuan yang buruk dan tidak adil, serta merusak nilai demokratis orang dalam hal kebebasan belajar dengan aman dan nyaman. Dampaknya, individu tidak dapat mengeluarkan seluruh potensi yang dimilikinya secara optimal (Rodkin, 
2012). Selain itu, Horner (dalam Polanin, Espelage, \& Pigott, 2012) menjelaskan bahwa perundungan merupakan perilaku agresi, intimidasi, atau pemaksaan secara berulang terhadap korban yang lebih lemah secara fisik, psikologis, status, kekuatan, dan faktor lainnya yang menunjukkan adanya ketidaksetaraan. Menurut Sullivan, Cleary, dan Sullivan (2004), bentuk-bentuk perundungan yang dapat terjadi adalah fisik, verbal, ancaman, hubungan, perusakan/pencurian barang, dan siber (cyberbullying).

Olweus (dalam Pierson, 2015) menyatakan tiga motif yang saling berhubungan menyebabkan munculnya perundungan yang berhubungan dengan teori belajar sosial adalah kebutuhan untuk mendominasi atau mendapatkan kekuatan, faktor keluarga, dan penguatan yang didapat dari lingkungan. Selain itu, seringkali alasan siswa melakukan perundungan awalnya hanya untuk bercanda (Scaglione \& Scaglione dalam Pierson, 2015). Akan tetapi, Olweus menyatakan bahwa orang yang terlibat dalam perundungan telah kehilangan rasa tanggung jawab atau perasaan bersalahnya (Pierson, 2015).

Fenomena perundungan ini juga menjadi keresahan guru dan orangtua di salah satu sekolah dasar swasta X dan Y, daerah Jakarta Selatan. Peneliti melakukan analisis kebutuhan pada akhir semester dua tahun ajaran 2017/2018. Berdasarkan hasil wawancara dengan kepala sekolah, kasus perundungan khususnya banyak terjadi diantara siswa kelas IV tahun ajaran 2017/2018 (Emel, komunikasi personal, 25 April 2018). Kepala sekolah menerima pengaduan setidaknya satu kasus besar yang akhirnya melibatkan orangtua dalam proses penyelesaian masalah, serta lebih dari dua kasus kecil lainnya yang berujung pada teguran dari pihak sekolah kepada siswa dalam waktu enam bulan terakhir. Berdasarkan hasil observasi kelas, tindakan yang diduga termasuk dalam perundungan adalah mengejek, mengancam, berkata kasar, memukul, menghadang saat berjalan, mendorong, menyembunyikan atau merusak barang, serta menjauhi teman.

Berdasarkan hasil wawancara wali kelas, perilaku perundungan cenderung terjadi pada siswa-siswa tertentu di kelas (Rosa \& Fetty, komunikasi personal, 17 Mei 2018). Banyak diantara siswa di kelas yang hanya menjadi pengikut pelaku-pelaku yang menginisiasi terjadinya perundungan. Ada pula siswa yang hanya diam atau berusaha menjauh saat melihat temannya menjadi korban. Di samping itu, terdapat beberapa siswa yang berusaha mengintervensi saat perundungan terjadi. Akan tetapi, intervensi yang dilakukan tidak konsisten karena bergantung pada banyaknya pelaku atau seberapa besar pengaruh yang dimiliki siswa tersebut di dalam kelas.

Berdasarkan hasil pengumpulan data melalui metode focus group discussion, alasan siswa hanya diam saat terjadinya perundungan adalah: takut dijauhi, pernah menjadi target ataupun takut akan menjadi target perundungan, memiliki pengalaman diejek setelah menegur pelaku, atau merasa bahwa korban layak mendapatkan perlakuan tersebut.

Menurut Rodkin (2012), keberhasilan perundungan bergantung pada beberapa faktor, diantaranya adalah karakteristik pelaku, hubungan antara pelaku dengan orang yang menjadi target korban, serta reaksi dari teman-temannya di kelas yang melihat kejadian perundungan tersebut. Perundungan seringkali terjadi saat teman-teman sekelas ikut menggoda, melecehkan, mendukung, membiarkan pelaku, dan tidak berusaha untuk mengintervensi. Jenis respon perilaku ini dimiliki oleh bystander atau saksi (Hawkins, Pepler, \& Craig; Lagerspetz, Bjorkqvist, Bertz, \& King dalam Polanin, dkk., 2012). Saksi 
atau bystander merupakan siswa-siswa yang hanya menyaksikan perundungan tanpa terlibat secara langsung sebagai korban atau pelaku dan dapat berdampak secara signifikan terhadap terjadinya perundungan (Padgett \& Notar, dalam Midgett, Doumas, \& Trull, 2018). Berdasarkan penelitian, terbukti bahwa lebih dari $80 \%$ orang-orang di sekitar korban hanya menjadi pengamat saat terjadinya perundungan (O'Connell, Pepler, \& Craig, dalam Polanin, dkk., 2012).

Saat saksi memberikan penguatan terhadap pelaku atau enggan melindungi korban, hasil penelitian menunjukkan peningkatan kecemasan sosial dan penolakan kelompok (peer rejection) pada siswa yang menjadi korban di tingkat sekolah dasar (Karna, Voeten, Poskiparta, \& Salmivalli, dalam Midgett, dkk., 2018). Sebaliknya, siswa yang berperan sebagai pembela korban menunjukkan tingkat dukungan sosial yang lebih tinggi dan perasaan kesepian yang lebih rendah (Olenik-Shemesh, dkk., dalam Midgett, dkk., 2018).

Secara umum, program intervensi yang sudah cukup meluas dipakai dalam lingkungan pendidikan adalah schoolbased bullying prevention and intervention (U.S. Department of Health and Human Services dalam Midgett, dkk., 2018). Selain itu, program psikoedukasi terhadap saksi yang dilakukan oleh Midgett, dkk. (2015) pada siswa kelas VI hingga kelas IX terbukti efektif meningkatkan kemampuan siswa dalam mengidentifikasi tipe perundungan, strategi spesifik yang dapat dipakai dalam mengintervensi perundungan, dan meningkatkan kepercayaan diri siswa terhadap kemampuannya untuk mengintervensi perundungan.

Intervensi mengubah saksi menjadi pembela korban merupakan salah satu komponen yang penting untuk menurunkan perundungan, namun masih sedikit penelitian yang sudah terbukti keberhasilannya pada tingkat siswa sekolah dasar (Karna dkk.; Williford dkk., dalam Midgett, dkk., 2018). Oleh karena itu, dibutuhkan program yang praktis untuk diimplementasikan pihak sekolah secara komprehensif dalam membantu pembela korban lebih percaya diri mencegah atau mengintervensi kejadian perundungan.

Program pelatihan dalam intervensi ini disusun berdasarkan modifikasi program psikoedukasi terhadap saksi oleh Midgett, dkk. (2015). Pelatihan dilakukan pada hari pertama tahun ajaran baru, setelah seluruh siswa kelas IVA dan IVB pada tahun ajaran 2017/2018 naik ke kelas V. Komposisi siswa yang naik ke kelas VA dan VB merupakan percampuran dari siswa di tingkat sebelumnya. Pelatihan dilakukan selama dua hari yang terbagi ke dalam tiga sesi. Durasi setiap sesi berkisar antara dua hingga tiga jam. Pada sesi pertama, siswa diberikan psikoedukasi terkait perundungan dan peran pembela di dalamnya. Sesi kedua diberikan materi tentang cara berperilaku asertif kepada pelaku maupun korban. Sesi terakhir adalah latihan menggunakan strategi "Stop, Walk, and Talk" yang dipakai saat berperan sebagai pembela.

Pelatihan ini diharapkan mampu meningkatkan perilaku asertif dan perilaku pembela siswa kelas V SD X Jakarta Selatan yang berperan sebagai saksi dalam perundungan. Post-test pertama dilakukan langsung setelah pelatihan selesai, sedangkan post-test kedua dilakukan pada hari ke-30 setelah pelatihan selesai diberikan. Dua hari setelah sesi pelatihan selesai dilaksanakan, peneliti menindaklanjuti intervensi dengan memberikan psikoedukasi kepada orangtua dalam bentuk infografis dan saran tertulis kepada wali kelas. Hal ini dengan tujuan untuk meningkatkan konsistensi penanganan perundungan secara 
menyeluruh. Selain itu, peneliti juga melakukan penguatan kepada peserta dengan melakukan sesi follow-up satu kali di minggu ketiga dan satu kali di minggu keempat setelah selesai dilakukannya intervensi. Pada sesi follow-up, seluruh siswa diberikan kesempatan untuk menceritakan pengalamannya dalam mempraktikkan strategi "Stop, Walk, and Talk" di sekolah setelah pelatihan diberikan. Antar peserta saling memberikan masukan saat ada peserta yang masih merasa belum berhasil menghentikan tindakan pelaku perundungan dengan mempraktikkan strategi "Stop, Walk, and Talk".

Rumusan masalah dalam penelitian ini adalah: (1) Apakah terdapat perbedaan yang signifikan antara perilaku asertif pada siswa kelas V SD X yang diberikan pelatihan dan siswa kelas V SD Y yang tidak diberikan pelatihan? (2) Apakah terdapat perbedaan yang signifikan antara perilaku pembela pada siswa kelas V SD $\mathrm{X}$ yang diberikan pelatihan dan siswa kelas V SD Y yang tidak diberikan pelatihan?

\section{Tujuan dan Manfaat Penelitian}

Penelitian ini bertujuan untuk melihat efektivitas program pelatihan terhadap perilaku asertif dan perilaku pembela pada siswa yang merupakan saksi dalam kejadian perundungan. Penelitian ini diharapkan dapat membantu pihak sekolah menurunkan perundungan. Hasil penelitian ini dapat dipakai oleh kepala sekolah, guru, konselor atau psikolog sekolah dalam mengintervensi perundungan yang terjadi di tingkat sekolah dasar dengan metode yang praktis, dalam waktu yang relatif singkat, dan hemat biaya. Selain itu, penelitian ini diharapkan dapat menambah data kajian empiris bagi pengembangan intervensi perundungan yang dipakai di Indonesia, khususnya dalam ranah pendidikan.

\section{Kajian Teori}

Definisi Perundungan

Papalia, Olds, dan Feldman (2008) menyatakan bahwa agresi dapat menjadi perundungan saat dilakukan dengan sengaja, secara berulang-ulang kepada target tertentu; dengan tipe korban yang biasanya lemah, rentan, dan tidak berdaya. Perundungan awalnya dideskripsikan oleh Olweus (dalam Polanin, dkk., 2012) sebagai perilaku individu atau sekelompok yang menggoda atau menyakiti individu lainnya secara berulang-ulang.

\section{Peran Saksi}

Peran yang muncul dalam kejadian perundungan adalah pelaku (bully), korban (victim), saksi (bystander), dan bully-victim. Menurut Yayasan Sejiwa (2008), pelaku merupakan inisiator perundungan. Pelaku umumnya memiliki fisik yang lebih besar dan kuat, namun tidak jarang juga memiliki bentuk fisik yang kecil atau sedang. Akan tetapi, ia pasti memiliki dominasi psikologis yang besar diantara teman-temannya. Hal ini membuatnya memiliki kekuatan dan kekuasaan di atas korban. Korban dalam perundungan tidak memiliki kekuatan untuk membela diri atau melawan (Midgett, dkk., 2018).

Peran berikutnya yang juga berhubungan dengan situasi perundungan adalah adanya saksi. Saksi dapat digolongkan menjadi empat kategori sesuai dengan responnya, yaitu: 1) asisten pelaku (assistant) yaitu siswa yang secara aktif dan langsung membantu pelaku menyiksa korban, 2) pendukung pelaku (reinforcer) yaitu siswa yang menertawakan atau hanya menyaksikan dalam situasi, 3) "outsider" yaitu siswa yang tidak terlibat atau pergi dari grup, 4) pembela korban (defender) yaitu siswa yang mengintervensi dan/atau menenangkan korban (Salmivalli; Salmivalli, Lagerspetz, Bjorkqvist, Osterman, \& Kaukiaiinen dalam Midgett, dkk., 2018). Di antara keempat peran ini, 
hanya peran pembela korban yang berhubungan dengan penurunan perundungan.

Pelaku akan terus melakukan perundungan karena adanya dukungan dari sekelilingnya saat ia menunjukkan aksinya (Sullivan, dkk., 2004). Individu yang hanya berperan sebagai saksi cenderung mengabaikan perasaan mereka saat melihat kejadian perundungan. Para saksi yang akhirnya tidak memberikan pertolongan pada korban berpotensi menjadi target perundungan berikutnya, sehingga mereka tidak berani untuk menolong korban (Sullivan, dkk., 2004). Pembela melakukan hal yang sebaliknya, yaitu menunjukkan sikap kontra terhadap perundungan. Sikap penolakan terhadap perundungan ini dapat berdampak besar untuk menghentikan pelaku.

Dampak perundungan bagi bystander atau saksi yang seringkali tidak berani menolong korban adalah pengembangan diri yang akan terhambat karena bertumbuh menjadi remaja yang penyendiri (Sullivan, dkk., 2004). Siswa yang bersangkutan juga akan cenderung sulit membangun hubungan yang sehat dengan orang lain.

Pelatihan untuk meningkatkan perilaku pembela merupakan intervensi yang lebih berdampak besar pada penurunan perilaku perundungan. Menurut Lee (2004), waktu yang lebih panjang dibutuhkan untuk mengubah perilaku korban dan pelaku. Hal inilah yang menjadikan intervensi mencegah atau mengatasi perundungan pada saksi mulai lebih banyak dikembangkan oleh para peneliti. Korban akan mendapatkan sistem pendukung yang lebih memadai dan perilaku pelaku akan menurun karena tidak diberikan penguatan atas perundungan yang dilakukannya. Selain itu, Midgett, dkk. (2018) menyampaikan bahwa program pelatihan yang komprehensif perlu dilakukan untuk meningkatkan kepercayaan diri siswa dalam mencegah ataupun mengintervensi terjadinya perundungan.

Program Pelatihan

Program pelatihan yang dipakai dalam penelitian ini merupakan modifikasi program pelatihan STAC yang dilakukan oleh Midgett dan Doumas (2016) pada siswa sekolah dasar kelas IV hingga VI. Pelatihan ini dimulai dengan memberikan psikoedukasi terkait perundungan, yang meliputi: 1) jenisjenis perundungan, 2) karakteristik siswa pelaku, korban, dan saksi perundungan 3) konsekuensi yang didapatkan oleh korban, pelaku, dan saksi dari perundungan 4) peran saksi dan pentingnya berperan sebagai pembela, 5) strategi "Stop, Walk, and Talk" yang dapat digunakan saat berperan sebagai pembela korban dalam situasi perundungan.

Modifikasi dari program pelatihan ini adalah penambahan materi perilaku asertif. Latihan kemampuan berperilaku secara asertif diperlukan untuk membuat pembela lebih percaya diri terhadap kemampuannya dalam menghentikan perundungan. Program intervensi ini salah satunya telah dibuktikan efektif meningkatkan perilaku asertif pada anak kelas II dan III di sekolah dasar negeri kelurahan Depok Jaya Kecamatan Pancoran Mas yang berisiko perundungan (Febrianti, 2013). Materi yang dibahas adalah pengenalan karakteristik reaksi non-asertif, agresif, dan asertif, serta resolusi konflik yang diambil saat menghadapi masalah.

Pada bagian akhir, materi terkait strategi yang dipakai oleh pembela saat menghadapi perundungan dimodifikasi berdasarkan pendekatan PBIS-BP (Positive Behavioral Interventions and Supports-Bullying Prevention) atau yang sering disebut sebagai Expect Respect (Pierson, 2015). PBIS-BP merupakan metode "Stop, Walk, and Talk" atau yang disingkat dengan SWaT saat berhadapan dengan situasi perundungan. Saat ada 
siswa yang menunjukkan ciri-ciri perilaku perundungan, siswa yang melihat segera mengatakan "STOP" dengan bahasa tubuh yang disesuaikan dan disepakati. Saat ada siswa yang menunjukkan perilaku perundungan, siswa yang menjadi korban "WALK" atau menjauh dari situasi tersebut. Jika pelaku terus mengikuti korban, siswa yang melihatnya harus berani "TALK" atau berbicara kepada orang dewasa atau orang lain yang bisa membantunya untuk menghentikan perundungan tersebut. Strategi ini merupakan salah satu strategi yang mudah diingat oleh siswa dan sesuai dengan konteks budaya yang ada di sekolah.

\section{Hipotesis}

Berdasarkan berbagai uraian di atas, maka hipotesis yang hendak diuji dalam penelitian ini adalah: (1) Terdapat perbedaan perilaku asertif yang signifikan antara siswa kelas V SD X yang diberikan pelatihan dan siswa kelas V SD Y yang tidak diberikan pelatihan; (2) Terdapat perbedaan perilaku pembela yang signifikan antara siswa kelas V SD $\mathrm{X}$ yang diberikan pelatihan dan siswa kelas V SD Y yang tidak diberikan pelatihan.

\section{METODE PENELITIAN}

\section{Identifikasi Variabel Penelitian}

Variabel bebas dalam penelitian ini adalah program pelatihan, sedangkan variabel terikat adalah perilaku asertif dan perilaku pembela partisipan dalam penelitian ini.

\section{Desain Penelitian}

Studi ini menguji efektivitas program pelatihan terhadap perilaku asertif dan perilaku pembela pada situasi perundungan di sekolah dasar kelas V. Desain penelitian ini merupakan pretest/post-test dengan between subjects (kelompok yang diberikan pelatihan dan kelompok yang tidak diberikan pelatihan).

\section{Partisipan Penelitian}

Partisipan dalam penelitian ini adalah siswa-siswi SD X dan SD Y kelas V tahun ajaran 2018/2019 di daerah Jakarta Selatan, yang pada tahun ajaran 2017/2018 merupakan siswa kelas IV. Teknik pemilihan sampel yang dipakai dalam penelitian ini adalah purposive sampling. Partisipan dipilih berdasarkan hasil sosiometri dan nominasi guru yang dilakukan pada saat seluruh siswa calon partisipan masih berada di kelas IV akhir tahun ajaran 2017/2018. Partisipan yang termasuk sebagai saksi adalah siswa yang tidak termasuk ke dalam kategori korban dan pelaku utama. Peneliti memberikan informed consent kepada orangtua dan jumlah partisipan akhir dalam penelitian ini adalah 46 siswa, yang terbagi menjadi dua kelompok. Kelompok satu adalah kelompok eksperimental yang mendapatkan program pelatihan dan terdiri dari 23 siswa SD $\mathrm{X}$ kelas $\mathrm{V}$. Kelompok dua adalah kelompok kontrol yang tidak mendapatkan program pelatihan dan terdiri dari 23 siswa SD Y kelas V. Perbandingan proporsi jumlah peserta dari setiap sekolah berdasarkan jenis kelamin dapat dilihat dalam tabel 1 .

Tabel 1. Proporsi jumlah peserta

\begin{tabular}{ccc}
\hline Jenis Kelamin & SD X & SD Y \\
\hline Perempuan & 17 siswa & 16 siswa \\
\hline Laki-laki & 6 siswa & 7 siswa \\
\hline
\end{tabular}

\section{Instrumen Penelitian \\ Perilaku Asertif}

Peneliti menggunakan skala perilaku asertif yang diadaptasi oleh Febrianti (2013) berdasarkan hasil penelitian Tololiu, Keliat, dan Daulima (2011). Jumlah item dalam skala perilaku asertif ini adalah 38 pernyataan, dengan 29 pernyataan positif dan 9 pernyataan negatif. Pilihan jawaban menggunakan skala likert, yaitu 0 (tidak pernah), 1 (kadang-kadang), 2 (sering), 3 (selalu) 
untuk perhitungan pernyataan positif, dan berlaku sebaliknya untuk pernyataan negatif.

\section{Perilaku Pembela}

Perilaku pembela diukur dengan menggunakan skala peran defender yang disusun oleh Irgahayu Madhina (2013) berdasarkan hasil penelitian tentang reaksi bystander oleh Rigby (2008) dan tips menjadi bystander yang baik oleh Beane (2008). Jumlah item dalam skala peran defender ini adalah 17 pernyataan, dengan 12 pernyataan positif dan 5 pernyataan negatif. Pilihan jawaban menggunakan skala likert, yaitu 1 (sangat tidak sesuai), 2 (tidak sesuai), 3 (agak tidak sesuai), 4 (agak sesuai), 5 (sesuai), 6 (sangat sesuai) untuk perhitungan pernyataan positif, dan berlaku sebaliknya untuk pernyataan negatif.

Strategi "Stop Walk, and Talk"

Peneliti menggunakan dua studi kasus untuk mengukur pengetahuan partisipan saat menggunakan strategi membela korban dalam situasi perundungan. Peneliti memberikan dua buah skenario pendek terkait situasi perundungan secara tertulis. Siswa diminta untuk menuliskan jawabannya sesuai dengan peran yang diceritakan dalam skenario perundungan tersebut. Contoh skenario yang tertulis adalah:

Terdapat satu kelompok siswa di kelasmu yang ingin menjahili salah satu siswa baru di kelas. Kelompok tersebut berencana untuk memasukkan mainan tikus-tikusan ke dalam tas siswa baru tersebut. Кати melihat saat mereka sedang memasukkan mainan tikustikusan ke dalam tas siswa tersebut. Tiba-tiba salah satu dari mereka ada yang menyadari keberadaan kamu di dalam kelas tersebut. Кати dipanggil dan diberikan ancaman bahwa mereka akan menyuruh teman-teman lainnya di kelas memusuhi kamu jika kamu mengadukan hal ini pada guru atau berusaha melindungi siswa baru tersebut. Apa yang akan kamu lakukan?

\section{Prosedur Penelitian}

Prosedur penelitian ini terbagi menjadi tiga tahap, yaitu persiapan, pelaksanaan, dan tindak lanjut. Pada tahap persiapan, peneliti melakukan analisis kebutuhan kepada pihak sekolah dan melakukan studi literatur terkait perundungan dan intervensi yang dapat dipakai pada saksi. Peneliti kemudian melakukan pembuatan modul program pelatihan dengan melakukan konsultasi kepada dosen pembimbing. Setelah itu, peneliti melakukan pemilihan partisipan dengan menggunakan sosiometri dan nominasi guru. Peneliti kemudian memberikan informed consent kepada calon partisipan untuk meminta persetujuan orangtua dalam mengikuti kegiatan pelatihan ini.

Pada tahap pelaksanaan, pelatihan dilakukan selama dua hari, yang terbagi ke dalam tiga sesi. Durasi sesi pertama adalah tiga jam, sesi kedua dan ketiga masing-masing dua setengah jam. Pada sesi pertama, peneliti memberikan lembar kuesioner pre-test kepada masing-masing peserta. Setelah itu, kegiatan dilanjutkan dengan menonton video, simulasi, refleksi diri, diskusi kelas dan kelompok kecil untuk memahami definisi perundungan, jenis-jenis perundungan, peran-peran yang ada dalam kejadian perundungan, penyebab perundungan, dampak perundungan, serta peran dari pembela korban. Pada sesi kedua, kegiatan yang dilakukan adalah pengisian kuesioner untuk mendapatkan gambaran perilaku asertif masing-masing peserta, diskusi kelas dan kelompok kecil, studi kasus untuk mendapatkan pemahaman dan manfaat perilaku asertif. Pada sesi ketiga, kegiatan yang dilakukan adalah pemahaman dan latihan menggunakan strategi "Stop, Walk, and Talk" saat berperan sebagai pembela dalam situasi perundungan. Sesi pelatihan kemudian ditutup dengan membuat poster sebagai komitmen siswa menentang perundungan 
dan mengisi lembar kuesioner post-test yang soalnya sama dengan pre-test.

Pada tahap tindak lanjut, peneliti memberikan rekomendasi kepada pihak sekolah secara tertulis terkait tindakan pencegahan dan resolusi konflik yang timbul dari perundungan di kelas $\mathrm{V}$, termasuk melibatkan orangtua di dalamnya. Selain itu, peneliti juga memberikan psikoedukasi kepada orangtua terkait perundungan melalui infografis. Peneliti melakukan penguatan kepada peserta dengan melakukan diskusi di dalam kelas selama dua pertemuan di minggu ketiga dan keempat setelah dilakukannya intervensi. Peserta diizinkan untuk membagikan cerita terkait pengalamannya membela korban dalam situasi perundungan dan saling bertukar pendapat terkait strategi yang telah dipakainya masing-masing. Pada hari ke-30 setelah dilakukannya intervensi, peserta kembali diberikan kuesioner post-test yang sama dengan soal kuesioner post-test pertama.

\section{Analisis Data}

Teknik analisis data yang digunakan untuk menguji hipotesis penelitian ini adalah Independent Sample $T$-test dengan program IBM SPSS Statistic Version 22. Teknik ini dipilih untuk membandingkan skor rata-rata antara dua kelompok, yaitu kelompok yang diberikan pelatihan dan kelompok yang tidak diberikan pelatihan.

\section{ANALISIS \& HASIL}

\section{Analisis Deskriptif}

Saat diberikan pre-test, rata-rata nilai perilaku asertif siswa pada kelompok yang diberikan pelatihan $(M=68.78, \quad S D=7.62) \quad$ lebih rendah dibandingkan kelompok yang tidak diberikan pelatihan $(M=71.74$, $S D=11.15)$. Hal ini menunjukkan bahwa sejak awal pemberian pre-test, kelompok yang tidak diberikan pelatihan sudah memiliki rata-rata nilai perilaku asertif yang lebih tinggi dibandingkan kelompok yang diberikan pelatihan. Pada saat diberikannya post-test $I$, rata-rata nilai perilaku asertif siswa pada kelompok yang diberikan pelatihan $(M=68.26$, $S D=8.98$ ) lebih rendah dibandingkan kelompok yang tidak diberikan pelatihan $(M=72.26, S D=9.80)$. Setelah pemberian post-test II, rata-rata nilai perilaku asertif siswa pada kelompok yang diberikan pelatihan $(M=68.57, \quad S D=8.78) \quad$ lebih rendah dibandingkan kelompok yang tidak diberikan pelatihan $(M=72.91$, $S D=9.07)$. Hal ini menunjukkan bahwa setelah dilakukannya pelatihan, nilai ratarata perilaku asertif pada kelompok yang diberikan pelatihan tetap lebih rendah dibandingkan kelompok yang tidak diberikan pelatihan.

Berdasarkan hasil analisis deskriptif pada saat pre-test, rata-rata nilai perilaku pembela siswa pada kelompok yang diberikan pelatihan $(M=73.61, \quad S D=9.71) \quad$ lebih tinggi dibandingkan kelompok yang tidak diberikan pelatihan $(M=72.83$, $S D=10.44)$. Hal ini menunjukkan bahwa saat awal pemberian pre-test, kelompok yang diberikan pelatihan memiliki ratarata nilai perilaku pembela yang lebih tinggi dibandingkan kelompok yang tidak diberikan pelatihan. Pada saat diberikannya post-test $I$, rata-rata nilai perilaku pembela siswa pada kelompok yang diberikan pelatihan $(M=72.65$, $S D=8.87$ ) lebih rendah dibandingkan kelompok yang tidak diberikan pelatihan $(M=75.09, S D=9.49)$. Setelah pemberian post-test II, rata-rata nilai perilaku pembela siswa pada kelompok yang diberikan pelatihan $(M=77.35$, $S D=11.48$ ) lebih rendah dibandingkan kelompok yang tidak diberikan pelatihan $(M=78.87, \quad S D=8.30)$. Hal ini menunjukkan bahwa setelah dilakukannya pelatihan, nilai rata-rata perilaku pembela pada kelompok yang tidak diberikan pelatihan menjadi lebih 
tinggi dibandingkan kelompok yang diberikan pelatihan.

Peneliti juga melakukan analisis uji deskriptif terhadap rata-rata nilai selisih pre-test dan post-test I, serta rata-rata nilai selisih pre-test dan post-test II pada kelompok yang diberikan pelatihan dan kelompok yang tidak diberikan pelatihan. Rata-rata nilai selisih pre-test dan posttest I perilaku asertif pada kelompok yang diberikan pelatihan $(M=-0.52$, $S D=7.12)$ sama dengan kelompok yang tidak diberikan pelatihan $(M=0.52$, $S D=5.10$ ). Nilai tersebut berarti rata-rata selisih perilaku asertif antara pre-test dan post-test I pada kelompok yang diberikan pelatihan sama dengan kelompok yang tidak diberikan pelatihan. Berikutnya, nilai rata-rata selisih pre-test dan post-test II perilaku asertif pada kelompok yang diberikan pelatihan $(M=-0.22, S D=8.63)$ lebih rendah dibandingkan kelompok yang tidak diberikan pelatihan $(M=1.17$, $S D=8.98$ ). Diantara keduanya, dapat disimpulkan bahwa pada kelompok yang diberikan pelatihan mengalami penurunan sedangkan pada kelompok yang tidak berikan pelatihan mengalami kenaikan nilai perilaku asertif setelah dilakukannya post-test I maupun post-test II.
Selanjutnya, berdasarkan hasil analisis deskriptif terhadap rata-rata nilai selisih pre-test dan post-test I perilaku pembela pada kelompok yang diberikan pelatihan $(M=-0.96, \quad S D=6.55) \quad$ lebih rendah dibandingkan kelompok yang tidak diberikan intervensi $(M=2.26$, $S D=8.27)$. Nilai tersebut berarti rata-rata selisih perilaku pembela antara pre-test dan post-test I pada kelompok yang diberikan pelatihan mengalami penurunan dan lebih rendah dibandingkan kelompok yang tidak diberikan pelatihan. Berikutnya, diperoleh rata-rata nilai selisih pre-test dan post-test II perilaku pembela pada kelompok yang diberikan pelatihan $(M=3.74, \quad S D=10.92) \quad$ lebih rendah dibandingkan kelompok yang tidak diberikan pelatihan $(M=6.04, S D=8.57)$. Hal ini menunjukkan bahwa rata-rata selisih perilaku pembela antara pre-test dan post-test II pada kelompok yang diberikan pelatihan mengalami peningkatan, namun lebih rendah dibandingkan kelompok yang tidak diberikan pelatihan.

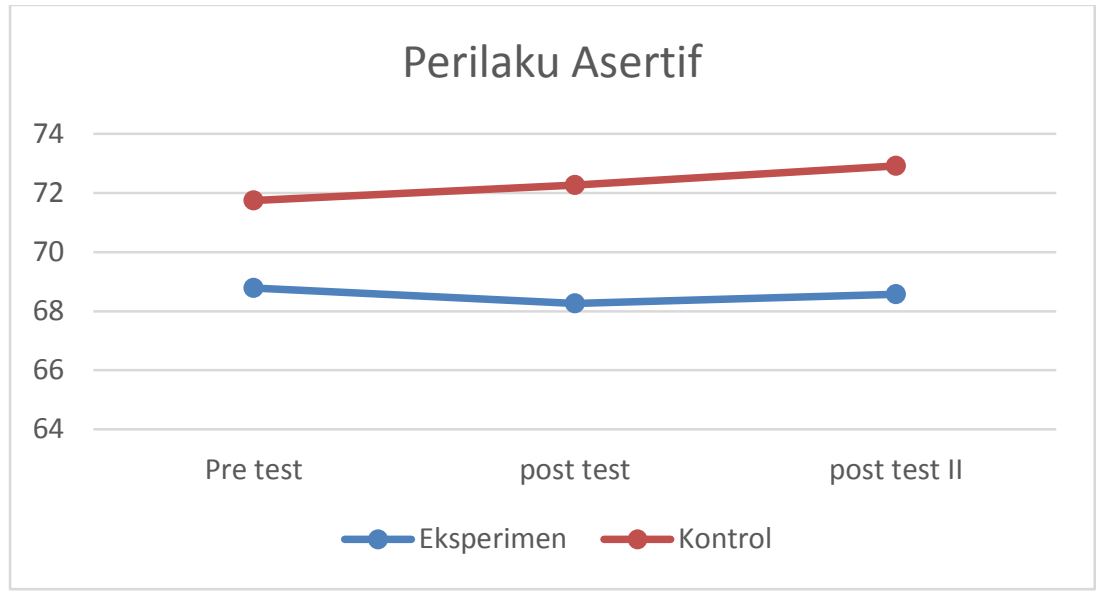

Gambar 1. Grafik peningkatan perilaku asertif 


\section{Perilaku pembela}

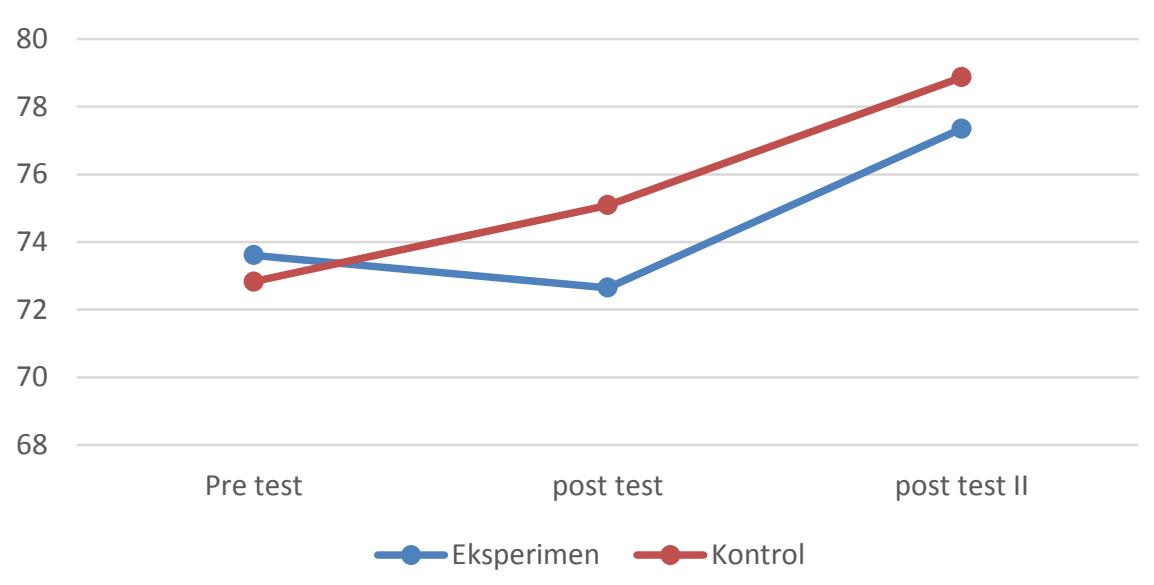

Gambar 2. Grafik peningkatan perilaku pembela

Tabel 2. Hasil uji deskriptif perilaku asertif

\begin{tabular}{lllrrr}
\hline & GRUP & N & Mean & Std. Deviation & Std. Error Mean \\
\hline Skor Pre Asertif & Eksperimen & 23 & 68.7826 & 7.61551 & 1.58794 \\
& Kontrol & 23 & 71.7391 & 11.15273 & 2.32551 \\
\hline Skor Post Asertif & Eksperimen & 23 & 68.2609 & 8.97581 & 1.87159 \\
& Kontrol & 23 & 72.2609 & 9.80361 & 2.04419 \\
\hline Skor Post Asertif II & Eksperimen & 23 & 68.5652 & 8.77924 & 1.83060 \\
& Kontrol & 23 & 72.9130 & 9.07000 & 1.89122 \\
\hline
\end{tabular}

Tabel 3. Hasil uji deskriptif perilaku pembela

\begin{tabular}{lllrrr}
\hline & GRUP & N & Mean & Std. Deviation & Std. Error Mean \\
\hline Skor Pre Defender & Eksperimen & 23 & 73.6087 & 9.70819 & 2.02430 \\
& Kontrol & 23 & 72.8261 & 10.43879 & 2.17664 \\
\hline \multirow{2}{*}{ Skor Post Defender } & Eksperimen & 23 & 72.6522 & 8.87083 & 1.84970 \\
& Kontrol & 23 & 75.0870 & 9.48642 & 1.97805 \\
\hline Skor Post Defender II & Eksperimen & 23 & 77.3478 & 11.47570 & 2.39285 \\
& Kontrol & 23 & 78.8696 & 8.30282 & 1.73126 \\
\hline
\end{tabular}

Tabel 4. Hasil uji deskriptif perilaku asertif selisih pre-test dan post-test

\begin{tabular}{lllrrr}
\hline & GRUP & N & Mean & Std. Deviation & Std. Error Mean \\
\hline \multirow{2}{*}{ Skor Pre-Post Asertif } & Eksperimen & 23 & -.5217 & 7.11509 & 1.48360 \\
& Kontrol & 23 & .5217 & 5.09786 & 1.06298 \\
\hline Skor Pre-Post Asertif II & Eksperimen & 23 & -.2174 & 8.62848 & 1.79916 \\
& Kontrol & 23 & 1.1739 & 8.97801 & 1.87205 \\
\hline
\end{tabular}

Tabel 5. Hasil uji deskriptif perilaku pembela selisih pre-test dan post-test

\begin{tabular}{lllrrr}
\hline & GRUP & N & Mean & Std. Deviation & Std. Error Mean \\
\hline \multirow{2}{*}{ Skor Pre-Post Defender } & Eksperimen & 23 & -.9565 & 6.55382 & 1.36657 \\
\cline { 2 - 6 } & Kontrol & 23 & 2.2609 & 8.27492 & 1.72544 \\
\hline \multirow{2}{*}{ Skor Pre-Post Defender II } & Eksperimen & 23 & 3.7391 & 10.91795 & 2.27655 \\
\cline { 2 - 6 } & Kontrol & 23 & 6.0435 & 8.56780 & 1.78651 \\
\hline
\end{tabular}




\section{Analisis Statistik}

Uji Beda

Berdasarkan hasil uji beda dengan Independent Sample T-test, diketahui bahwa tidak terdapat perbedaan yang signifikan antara selisih skor pre-test dan post-test I perilaku asertif pada kelompok yang diberikan pelatihan dan kelompok yang tidak diberikan pelatihan $t(44)=-$ $0.572, \mathrm{p}=0.570$. Tidak terdapat perbedaan yang signifikan antara selisih skor pre-test dan post-test II perilaku asertif pada kelompok yang diberikan pelatihan dan kelompok yang tidak diberikan pelatihan $\mathrm{t}(44)=-0536, \mathrm{p}=0.595$. Hal ini menunjukkan bahwa kelompok yang diberikan pelatihan dan kelompok yang tidak diberikan pelatihan memiliki perilaku asertif yang sama baik setelah post-test I maupun setelah post-test II. Selain itu, tidak terdapat perbedaan yang signifikan antara selisih skor pre-test dan post-test I perilaku pembela pada kelompok yang diberikan pelatihan dan kelompok yang tidak diberikan pelatihan $\mathrm{t}(44)=-1.462, \mathrm{p}=0.151$. Tidak terdapat perbedaan yang signifikan antara selisih skor pre-test dan post-test II perilaku pembela pada kelompok yang diberikan pelatihan dan kelompok yang tidak diberikan pelatihan $\mathrm{t}(44)=-0.796$, $\mathrm{p}=0.430$. Hal ini menunjukkan bahwa kelompok yang diberikan pelatihan dan kelompok yang tidak diberikan pelatihan memiliki perilaku pembela yang sama baik setelah post-test I maupun setelah post-test II.

Tabel 6. Hasil uji beda perilaku asertif

\begin{tabular}{ccccccc}
\hline & & & & Perbedaan & Perbedaan \\
& $\mathrm{F}$ & $\mathrm{t}$ & df & Signifkansi & Mean & SD \\
\hline Skor Pre-Post Asertif & 3.086 & -.572 & 44 & .570 & -1.04348 & 1.82510 \\
\hline Skor Pre-Post Asertif II & .532 & -.536 & 44 & .595 & -1.39130 & 2.59645 \\
\hline
\end{tabular}

Tabel 7. Hasil uji beda perilaku pembela

\begin{tabular}{ccccccc}
\hline & & & & & Perbedaan & Perbedaan \\
& $\mathrm{F}$ & $\mathrm{t}$ & df & Signifikansi & Mean & SD \\
\hline Skor Pre-Post Defender & .747 & -1.462 & 44 & .151 & -3.21739 & 2.20106 \\
\hline Skor Pre-Post Defender II & .854 & -.796 & 44 & .430 & -2.30435 & 2.89384 \\
\hline
\end{tabular}

\section{Analisis Tambahan}

Peneliti melakukan analisis tambahan yang dilakukan secara kualitatif melalui studi kasus dan metode wawancara kepada wali kelas. Berdasarkan hasil studi kasus yang dikerjakan oleh peserta pada kelompok yang diberikan pelatihan, terdapat peningkatan kualitas jawaban pada lima siswa. Peserta yang mengalami peningkatan kualitas jawaban ini terlihat menggunakan strategi lain dalam membela korban, diantaranya mencari bantuan kepada orang dewasa, menunjukkan sikap empati terhadap korban dengan mendatanginya untuk menanyakan kejadian yang dialami, perasaannya saat ini, dan menghiburnya. Akan tetapi, masih terdapat peserta yang cenderung menunjukkan perilaku saksi tipe pendukung pelaku dengan ikut menertawakan atau sekedar menonton saat adanya kejadian perundungan.

Berdasarkan hasil wawancara wali kelas VA dan VB, jumlah pembela di kelas VA cenderung meningkat, sedangkan jumlah pembela di kelas VB masih cenderung sama. Akan tetapi, intensitas perilaku pembela di kelas VB lebih besar dibandingkan pembela di kelas VA. Hal ini disebabkan oleh dinamika pertemanan di kelas VA dan VB yang sudah berbeda dibandingkan saat siswa masih berada di kelas IV tahun ajaran lalu. Selain itu, pelaku yang saat ini lebih banyak berkumpul di kelas VB dibandingkan kelas VA memberikan dorongan yang lebih besar bagi siswa untuk membela korban. 


\section{DISKUSI}

Secara kuantitatif, hasil penelitian ini menunjukkan bahwa tidak terdapat perbedaan perilaku asertif dan perilaku pembela yang signifikan antara kelompok yang diberikan intervensi dan kelompok yang tidak diberikan intervensi. Namun secara kualitatif, ditinjau dari kualitas dan variasi jenis perilaku pembela, telah menunjukkan adanya peningkatan perilaku pembela dibandingkan dengan sebelum diberikan intervensi.

Perilaku pembela sebelumnya hanya terbatas menegur pelaku dengan cara yang agresif, namun saat ini siswa sudah dapat menggunakan cara "Stop, Walk, and Talk". Setidaknya lima siswa mengalami perubahan sesudah diberikan intervensi. Sebelumnya, lima siswa tersebut diidentifikasi sebagai siswa dengan nilai perilaku asertif dan perilaku pembela terbawah yang menggunakan cara yang agresif dalam menegur pelaku maupun bersikap enggan menolong korban. Setelah diberikan intervensi, lima siswa tersebut menunjukkan perubahan sikap menjadi pembela yang aktif dengan menggunakan metode "Stop, Walk, and Talk". Seperti yang telah disampaikan oleh Pierson (2015), bahwa strategi ini cukup mudah diingat dan dipraktikkan secara sederhana oleh siswa sekolah dasar. Guru menilai bahwa terdapat perubahan intensitas membela korban yang semakin kuat pada siswa yang diberikan pelatihan, meskipun hal ini hanya signifikan dirasakan di dalam dinamika satu kelas.

Tidak adanya perbedaan yang signifikan secara kuantitatif dapat disebabkan oleh beberapa hal. Secara kuantitatif, pada skala perilaku asertif, kelompok yang tidak diberikan intervensi memiliki skor pre-test yang lebih tinggi dibandingkan dengan kelompok yang diberikan intervensi. Hal ini menunjukkan bahwa kelompok yang tidak diberikan intervensi sejak awal sudah memiliki tingkat perilaku asertif yang lebih tinggi dibandingkan kelompok yang diberikan intervensi.

Perubahan komposisi siswa kelas V di tahun ajaran baru ini berdampak pada dinamika pertemanan yang berbeda. Jumlah pelaku yang lebih banyak berkumpul pada suatu kelas membuat kelompoknya semakin kuat. Hal ini membuat kelompok siswa yang berperan sebagai pembela pun semakin kuat. Adapula kelompok pelaku yang tidak terlalu kuat menunjukkan perilaku perundungan secara terbuka, namun membuat pembela bersikap pasif. Hal ini kemungkinan membuat pembela di kelas tersebut tidak memiliki dorongan yang kuat untuk menunjukkan sikap aktifnya sebagai pembela.

Hal berikutnya yang dapat mempengaruhi tidak adanya perbedaan yang signifikan disebabkan oleh kurangnya konsistensi yang ditunjukkan oleh orang dewasa di sekitar partisipan. Sejalan dengan hasil penelitian yang disampaikan oleh Beckford (2015), bahwa dukungan dari orang dewasa di sekolah (misal, wali kelas) maupun di lingkungan keluarga (misal, orangtua) akan mempengaruhi siswa bertindak sebagai pembela. Orang dewasa dapat membantu siswa keluar dari perasaan frustrasinya dan berani mengubah keadaan di sekitarnya.

Penelitian berikutnya juga perlu melakukan studi literatur kembali terkait variabel lain yang dapat mempengaruhi sikap dan perilaku pembela. Variabel lain yang dapat berpengaruh pada peningkatan perilaku pembela adalah kemampuan berempati. Seperti program intervensi bully-proofing yang dikembangkan oleh Garrity, Jens, Porter, Sager dan ShortCamilli (dalam Midgett \& Doumas, 2016), aspek empati termasuk didalamnya yang perlu diajarkan sebagai strategi pembela korban. Menurut Staub (dalam Dworetzky, 1984), seseorang memerlukan dua faktor penting dalam menolong, yaitu kemampuan atau pengetahuan cara yang efektif untuk menolong serta empati. Selain itu, variabel lain yang perlu dipertimbangkan adalah perilaku prososial. Eisenberg (dalam Griese 
\& Buhs, 2014) juga menyampaikan bahwa anak yang menunjukkan perilaku prososial cenderung lebih disukai oleh kelompoknya sehingga memiliki interaksi dalam kelompok yang positif.

Program intervensi yang sudah banyak berhasil mengurangi perundungan sejauh ini memerlukan pendekatan sekolah secara menyeluruh. Sebagai contoh program KiVa yang sudah banyak dipakai sejak tahun 2011 (Karna dalam Voeten, Little, Poskiparta, Kaljonen, \& Salmivalli dalam Midgett, dkk., 2015). Program KiVa menerapkan dua komponen, yaitu universal action (pelatihan bagi siswa di kelas) dan indicated actions (melibatkan seluruh pegawai di sekolah dan siswa dalam mengintervensi saat adanya kejadian perundungan).

Hal lain yang mempengaruhi hasil intervensi ini adalah durasi pemberian intervensi yang cukup panjang dalam setiap pertemuannya. Durasi kurang lebih empat jam dalam setiap pertemuan membuat atensi peserta mudah terdistrak. Akan lebih efektif jika waktu pelatihan dapat dibagi ke dalam beberapa hari dengan durasi per sesi yang dipersingkat. Hal ini membuat siswa lebih optimal dalam mengikuti program pelatihan. Selain itu, dibutuhkan waktu yang cukup panjang untuk mencapai perubahan tingkah laku. Dengan jumlah dua sesi pelatihan yang diberikan, hal ini belum dapat mencapai perubahan pada level perilaku. Kegiatan role play dan simulasi kasus kurang banyak dilakukan karena adanya keterbatasan waktu.

Faktor lain yang dapat mempengaruhi hasil penelitian ini adalah self-report yang dilakukan oleh siswa sekolah dasar dapat bersifat bias. Hal ini dapat disebabkan oleh siswa yang tidak benar-benar memahami isi dari setiap item atau item yang memiliki tingkat social desirability yang tinggi. Hal ini membuat siswa cenderung memberikan rating yang tinggi pada item yang positif dan rating yang rendah pada item yang negatif.

\section{SIMPULAN}

Berdasarkan hasil penelitian ini dapat diketahui bahwa tidak terdapat perbedaan yang signifikan perilaku asertif dan perilaku pembela antara siswa kelas V SD X yang diberikan pelatihan dan siswa kelas V SD Y yang tidak diberikan pelatihan. Akan tetapi, berdasarkan hasil analisis kualitatif studi kasus yang diberikan kepada peserta serta wawancara pada wali kelas terkait perilaku pembela, kelompok yang diberikan pelatihan sudah menunjukkan adanya peningkatan penggunaan strategi SWaT saat melihat temannya mengalami perundungan dibandingkan dengan kelompok yang tidak diberikan pelatihan.

\section{SARAN}

Intervensi kasus perundungan yang ideal sebaiknya dapat dilakukan secara menyeluruh. Tidak hanya siswa yang diberikan intervensi, pihak lain yang terlibat dalam lingkungan sekolah perlu untuk diberikan psikoedukasi untuk dapat mencegah dan mengatasi perundungan dengan cara yang konsisten. Pihak lain yang perlu terlibat di dalamnya adalah guru, kepala sekolah, pegawai sekolah, hingga orangtua siswa.

Dalam mencapai sasaran perubahan tingkah laku, dibutuhkan rancangan kegiatan pelatihan yang lebih banyak lebih banyak menekankan kepada pemberian kegiatan bermain peran dengan kasus yang bervariasi. Hal ini untuk membentuk tingkah laku yang diharapkan. Durasi program pelatihan perlu untuk dipertimbangkan agar siswa diberikan kesempatan untuk mengaplikasikan kemampuannya setelah setiap sesi diberikan.

Kemungkinan penggunaan metode self-report yang dapat menyebabkan bias pada siswa sekolah dasar perlu untuk dipertimbangkan di penelitian selanjutnya. Akan lebih baik jika penelitian selanjutnya dapat menggunakan metode penilaian frekuensi perilaku membela atau perilaku 
asertif siswa yang dilakukan oleh teman sebaya dan guru. Hal ini untuk mendapatkan validitas dan reliabilitas hasil pengukuran yang baik.

\section{DAFTAR PUSTAKA}

Beane, A. L. (2008). Protect Your Child from Bullying. San Fransisco: Jossey Bass.

Beckford, N. A. (2015). Bullies and Bystanders. Tesis. Ohio: Master of Education Degree in Educational Psychology, The University of Toledo.

Craig, J. T. (2016). Children's peer relationship quality and changes in peer victimization: The search for viable intervention targets. Disertasi. Kansas: Doctor of Philosphy in Psychology, University of Arkansas.

Dworetzky, J. P. (1984). Introduction to Child Development ( $2^{\text {nd }}$ ed.). Minnesota: West Publishing Co.

Febrianti, D. (2013). Pengaruh Latihan Perilaku Asertif pada Anak Usia Sekolah, Orangtua, Guru dalam Mengatasi Bullying di Kelurahan Depok Jaya. Tesis. Universitas Indonesia: Fakultas Ilmu Keperawatan.

Griese, E. R., \& Buhs, E. S. (2014). Prosocial Behavior as a Protective Factor for Children's Peer Victimization. Journal of Youth and Adolescence,43(7), 10521065. https://doi.org/10.1007/s10964013-0046-y

Lee. C. (2004). Preventing bullying in schools: a guide for teachers and other professionals. London: Paul Chapman Publishing.

Madhina, I. (2013). Hubungan Antara Tanggung Jawab dan Peran Defender dalam Bullying pada Siswa SD. Skripsi. Universitas Indonesia: Fakultas Psikologi.

Midgett, A., Doumas, D., Sears, D., Lundquist, A., \& Hausheer, R. (2015). A Bystander Bullying Psychoeducation Program With Middle School Students: A Preliminary Report. The Counselor, 5(4), Professional https://doi.org/10.15241/am.5.4.486

Midgett, A., \& Doumas, D. M. (2016). Training Elementary School Students to Intervene as Peer-Advocates to Stop Bullying at School: A Pilot Study. Journal of Creativity in Mental Health,11(3-4),
353-365.

https://doi.org/10.1080/15401383.2016.1 164645

Midgett, A., Doumas, D., \& Trull, R. (2018). Evaluation of a Brief, School-Based Bullying Bystander Intervention for Elementary School Students. Professional School Counseling, 20(1), 172-183. doi: 10.5330/1096-240920.1.172

Papalia, D., Olds, S., \& Feldman, R. (2008). Human Development $\left(11^{\text {th }}\right.$ ed.). New York: McGraw-Hill.

Pierson, D. C. (2015). Bullying prevention within positive behavior interventions and supports: A study of five elementary schools. Disertasi. Illinois: College of Education, the University of St. Francis.

Polanin, J., Espelage, D. L., \& Pigott, T. D. (2012). A Meta-Analysis of SchoolBased Bullying Prevention Programs' Effects on Bystander Intervention Behavior. School Psychology Review, 4l(1),19p. https://doi.org/10.1128/AAC.00466-11

Rigby, K. (2008). Children and Bullying. Malden: Blackwell Publishing Ltd.

Rodkin, P. C. (2012). Bullying and children's peer relationships. Collegues, 8(4), 1-6.

Sindonews.com (2017). Indonesia Tempati Posisi Tertinggi Perundungan di ASEAN, diunduh dari https://nasional.sindonews.com/read/122 3442/15/indonesia-tempati-posisitertinggi-perundungan-di-asean1500880739 pada 29 Mei 2018.

Sullivan, K., Cleary, M., \& Sullivan, G. (2004). Bullying in secondary schools: What it looks like and how to manage it. London: Paul Chapman.

Tololiu, T, Keliat, B.A., \& Daulima, N.H.C. (2011). An effective assertive behavior training in avoiding bullying to adolescent at Depok, Indonesia. Journal of Psychosocial Nursing \& Mental Health Services.

Correspondence:

Veronica Novelina Parapat, Universitas Indonesia, Lkr.Kampus Raya Blok Mawar, Depok, Indonesia Tel. 021-7863520,Email: veronicaparapat@gmail.com 